\title{
FAMILY VIOLENCE AND THE CIVIL LAW/CRIMINAL LAW INTERPLAY - SOME REFLECTIONS
}

\author{
Bill Atkin*
}

Family violence is increasingly recognised as a serious social problem. That awareness has led to much legislation being passed to address the problem. The legislation has evolved from distinct civil and criminal roots to a point where the two closely interact. This article explores the sources and consequences of this interplay of the civil and the criminal in relation to family violence. The piece is dedicated to long-time colleague, Professor John Prebble, even though the topic does not grapple with his area of great expertise, the law of taxation.

\section{INTRODUCTION}

Violence in the home is today well recognised as a major social problem. It can take many forms, but child abuse and what has commonly been referred to as domestic violence, now in New Zealand called "family violence", are the two standout examples. Addressing the problem goes well beyond the legal framework that is mostly found in legislation. It has political, social, cultural, health, educational and professional angles, and many more. This article focuses on a few aspects of the law on family abuse. Despite major revisions of the law in the last few years, it has grown up like the proverbial Topsy. In spite of many reports and consultation processes, the law looks far from coordinated and consistent.

One of the themes of this article is to identify the extent to which the traditional division between the civil law and the criminal law has broken down. Ignoring such a division is out of most lawyers' comfort zone. Yet, this is looking increasingly inevitable, maybe rightly so. How far this can go, though, is not something that has been explored in great depth. This article merely scrapes the surface. First, the scene is set by outlining the developments in the law over the past decade, including both family violence and child protection. Secondly, this article uses civil law examples of family violence to illustrate the interplay with criminal law. This is then followed by a discussion on the ways in which

* Professor of Law, Victoria University of Wellington | Te Herenga Waka. I am especially grateful for the superb assistance that Aidan Economu provided in relation to this article. 
the criminal law draws on the civil law. While the distinction between the two has become blurred, ways in which it remains significant are briefly flagged.

\section{DISCORDANT REFORM EFFORTS}

Over the past decade, there has been political impetus to reform the law on home abuse. By and large (but certainly not always), a bipartisan approach has enabled the passage of important new legislation. In addition, there have been fresh endeavours to implement practices and policies aimed at stopping abuse. This process has not been trouble-free. For example, much media attention has been paid to the uplifting of children at birth, usually Māori babies. How to deal with this fraught situation is a distinct and ongoing inquiry and is outside the scope of this article. ${ }^{1}$

A further issue is that the law has for a long time gone down two very different tracks, almost polar opposites. The Children, Young Persons, and Their Families Act 1989, now called the Oranga Tamariki Act 1989 (OTA) or Children's and Young People's Well-being Act 1989, ${ }^{2}$ was passed after major reversals in policy to take account of deep-seated objections from Māori and Pasifika. ${ }^{3}$ The centrepiece became the family group conference (FGC), with the family/whānau having the primary role in deciding what should happen to an abused or neglected child. Likewise, in the part of the OTA dealing with youth justice, the FGC has a vital place in determining outcomes for the young offender. In the last decade, three significant batches of amendments have been made, culminating in a piece of legislation with many added sections, subsections and paragraphs. In 2016, the first batch brought in new provisions relating to "subsequent children", which shifted the onus of proof to a parent who has had care issues in the past, and "special guardianship", which relates to children in permanent care. ${ }^{4}$ In 2017, a second batch of changes came into force, including an important new statement about child participation in s 11 of the OTA. ${ }^{5}$ On 1 July 2019, the most important body of amendments included significant references to the Treaty of Waitangi/Te Tiriti o Waitangi, the United Nations Convention on the Rights of the Child and the United Nations Convention on the Rights of Persons

1 See Nicola Taylor and Ruth Ballantyne "Protecting children, families, and whānau from family violence" in Mark Henaghan and Bill Atkin (eds) Family Law Policy in New Zealand (5th ed, LexisNexis, Wellington, 2020) 99 at [3.3.3].

2 The name change was effected on 14 July 2017 by the Children, Young Persons, and Their Families (Oranga Tamariki) Legislation Act 2017, s 5.

3 See especially Puao-Te-Ata-Tu: The Report of the Ministerial Advisory Committee on a Māori Perspective for the Department of Social Welfare (Department of Social Welfare, June 1986).

4 Children, Young Persons, and Their Families (Vulnerable Children) Amendment Act 2014, ss 9 and 22 (entered into force 30 June 2016).

5 Children, Young Persons, and Their Families (Advocacy, Workforce, and Age Settings) Amendment Act 2016 (entered into force 1 April 2017). 
with Disabilities. ${ }^{6}$ This massive amount of legislative amendments should have led to a fresh new Act, but that did not happen. In fact, another piece of legislation had been passed in 2014, which simply added to the legislative shambles. The Vulnerable Children Act 2014 was aimed at higher level matters rather than specific cases. The title attracted criticism. Soon after the change of government in 2017, major amendments were made and the title was changed to the Children's Act 2014. ${ }^{7}$ The Child Poverty Reduction Act 2018 was a companion piece. The Children's Act 2014 provides for a strategy for improving children's well-being (not limited to "vulnerable children"), child protection policies for organisations that deal with children, and safety checking of workers having regular contact with children. The 2018 amendments added a Treaty clause and references to the two Conventions mentioned above.

The other track for dealing with family abuse is essentially that found in the Family Violence Act 2018 (FVA), in force from 1 July 2019. It has nothing about FGCs, the Treaty, the Conventions or the participation of children. It deals primarily with adult abuse, but it has implications for children, and abused children can be assisted by the Act. The centrepiece is the protection order that the Family Court can grant under pt 4 , often on a without notice application where there is supposed to be an element of urgency.

The FVA replaced the Domestic Violence Act 1995. The latter had been regarded as state of the art in its day, but, like the child protection legislation, it has been the subject of amendment over the past decade. So, from 1 July 2010, a new part was added to the Act to provide for Police safety orders. ${ }^{8}$ Another amendment in 2013 saw more changes including the addition of "financial or economic abuse" as a category of "domestic violence". ${ }^{9}$ Ministerial agitation about the problem of domestic violence then led to an extensive round of consultation by the Ministry of Justice. ${ }^{10}$ This resulted in

6 Children, Young Persons, and Their Families (Oranga Tamariki) Legislation Act, ss 9, 11 and 14; Convention on the Rights of the Child 1577 UNTS 3 (opened for signature 20 November 1989, entered into force 2 September 1990); and Convention on the Rights of Persons with Disabilities 2515 UNTS 3 (opened for signature 13 December 2006, entered into force 3 May 2008). The Children, Young Persons, and Their Families (Oranga Tamariki) Legislation Bill 2016 (224-3) was passed by one vote: (6 July 2017) 723 NZPD 19427. On the Treaty, see the Oranga Tamariki Act 1989 [OTA], ss 4(1)(f) and 7AA, and on the Conventions, see s 5(1)(b)(i).

7 See Bill Atkin "'Vulnerable' Children, Cultural and Social Realities and Regulation: Moving towards Early Intervention in New Zealand" in Carol Rogerson and others (eds) Family Law and Family Realities (Eleven International Publishing, The Hague, 2019) 403.

8 Domestic Violence Act 1995, pt 6A, inserted by the Domestic Violence Amendment Act 2009, s 9. The capital letter for "Police" is in the legislation.

9 Domestic Violence Act, s 3(2)(c)(iva), inserted by the Domestic Violence Amendment Act 2013, s 5.

10 See Ministry of Justice Strengthening New Zealand's legislative response to family violence: A public discussion document (2015) 
the Family and Whānau Violence Legislation Bill 2017. ${ }^{11}$ It contained amendments to the 1995 Act, plus a number of changes relating to the Crimes Act 1961 and criminal procedure. A change of government kept the impetus going but various changes were made. From a legal point of view, the major one was that the title changed, and a completely new Act replaced the Domestic Violence Act: The Family Violence Act 2018. The change in name is significant as the juxtaposition of whānau and violence was extremely awkward. Even the title "Family Violence" is potentially misleading, as the FVA deals with only some aspects of family abuse. As discussed above, abuse of children is primarily covered by the very different OTA. Internationally, the title could be misleading as "domestic violence" tends to be the currency when referring to adult abuse. Accompanying the FVA was the Family Violence (Amendments) Act 2018. This dealt with the criminal law amendments to various Acts, plus some mostly consequential changes to the Care of Children Act 2004 (COCA). Also enacted, but as a separate initiative, was the Domestic Violence-Victims' Protection Act 2018. This was introduced as a Member's Bill in the name of Jan Logie MP, who by the time of its enactment, had become Parliamentary Under-Secretary to the Minister of Justice with a focus on domestic and sexual violence issues. The Act amends several pieces of legislation, covering flexible working time, domestic violence leave from work and non-discrimination under the Human Rights Act 1993. The passage of the Bill was not supported by opposition parties, unlike the other recent family violence legislation, but similar to the latest revisions to the OTA where Parliament was split.

The two tracks just sketched reveal differing legal policies and practices when dealing with abuse. The sketch belies the fuller picture, because other laws are affected, including the COCA and the criminal law. The differences reflect the roles played by different government departments and, despite efforts to get cross-agency co-operation (discussed later), historical ways in which the law has been formulated remain entrenched. At the same time, as foreshadowed above, some of the historical divisions in the law are starting to look less easy to defend. Let us now explore the civil law/criminal law divide, with a focus on what we now call family violence.

\section{THE CIVIL LAW OF FAMILY VIOLENCE AND ITS INTERPLAY WITH THE CRIMINAL LAW}

\section{A Breach of Protection Order}

The offence in s 112 of the FVA is the most obvious and longstanding connection between the FVA and the criminal law. Under the FVA, the court can grant protection orders and various property orders relating to occupation, tenancies and furniture. The aim of a protection order is to prevent the abuser from committing family violence in the future. Subject to exceptions, this includes conditions about not contacting the victim, but there are also standard conditions relating to weapons. ${ }^{12}$ Special

11 Family and Whānau Violence Legislation Bill 2017 (247-1).

12 Family Violence Act 2018 [FVA], ss 90-102. 
conditions can be imposed in relation to the parties' specific situation. ${ }^{13}$ As for property orders, the typical effect of an order is for the abuser to leave the property in question and allow the victim use of furniture, household appliances and household effects. ${ }^{14}$ Section 112 creates an offence for breach of a protection order or related property order. A "reasonable excuse" for breaching the order is a defence. ${ }^{15}$ Section 113 provides for an accompanying power to arrest without warrant. An abuser may also be required to undergo an assessment and attend an appropriate programme, such as one to address anger management. ${ }^{16}$ Failure without reasonable excuse to comply with a direction to undergo an assessment and attend an appropriate programme is also an offence, but this is set out in s 211 .

The real significance of s 112 for the purposes of this article is that the criminal law, in determining whether an offence has been committed, may have to ask whether family violence as defined in the FVA has been inflicted. ${ }^{17}$ This takes us to the meaning of "family violence" in ss 9-11. These sections are extensive, but in summary cover physical, sexual and psychological abuse. The point is that a criminal court, rather than the Family Court, may make important rulings about the meaning of "family violence", with consequential effects for future civil cases. Given that in 2020 there were 5,632 charges laid under s $112,{ }^{18}$ the chances of a criminal court having a major say in the interpretation of "family violence" are considerable.

The stand-out example of this relates to financial and economic abuse, added to the law, as noted above, in 2013. In Cooper $v R,{ }^{19}$ a protection order existed against Cooper. He and his wife reached an agreement during mediation to try and resolve their relationship property matters, but this did not in fact lead to a binding settlement. ${ }^{20}$ However, in anticipation of settlement, the parties signed a bank withdrawal form for $\$ 70,000$ from the family trust. ${ }^{21}$ Cooper managed to deceive a legal executive at his solicitor's firm so as to remove the form and get it cashed at the bank. ${ }^{22}$ The question was whether this action in itself amounted to financial or economic abuse, or whether it had to be accompanied by evidence of psychological distress. Financial or economic abuse is a subset of psychological abuse,

13 Sections 103-104.

14 Sections 119, 123, 131 and 137.

15 Section 112(2).

16 Sections 188 and 198.

17 This is the language of the Act. See the definition of "inflict family violence" in s 8 .

18 See Table 4a: Number and percentage of charges for breach of protection order offences, by offence type, 2011-2020, available at "Data tables" Ministry of Justice <www.justice.govt.nz>.

19 Cooper v R [2018] NZCA 159, [2018] NZFLR 442.

20 At [6]-[7].

21 At [6].

22 At [7]-[9]. 
but can it in effect stand on its own? The Court of Appeal held that it could, accepting that "the financial variant of psychological abuse is concerned with the exertion of control by the perpetrator rather than the psychological impact upon the protected person". ${ }^{23}$

This decision is the leading one on financial abuse, hailing from the criminal law but valid for the civil law. It was decided under the Domestic Violence Act but remains a precedent for the FVA. Two subtexts relating to family violence emerge from the decision. First, the mention of "control" is reflected in the newly minted s 9(3)(a) whereby a pattern of behaviour that is "coercive or controlling" may amount to violence. ${ }^{24}$ The other subtext is elder abuse. One of the principles of the FVA is that old age "may mean that people are particularly vulnerable to family violence". ${ }^{25}$ Age, along with "disability, health condition, or any other cause", may be the basis for psychological abuse where it involves the victim's inability to withdraw from the care or charge of another person, or hindering or removing access to devices, medication and other support that affects or is likely to affect the victim's quality of life. ${ }^{26}$ This comes straight after financial abuse in the s 11 definition of psychological abuse, not, it is suggested, by accident, but because financial abuse is regarded as a prevalent form of elder abuse. ${ }^{27}$ Thus, Cooper, a criminal law case on financial abuse, can be seen not as an isolated set of unusual facts, but as fitting into the broader matrix of family violence. More specifically, it arguably makes it easier to use the FVA to assist victims of elder abuse.

\section{B Protection Orders on Sentencing}

One of the reforms that the Domestic Violence (Enhancing Safety) Bill 2008 brought in is the power of a criminal court to grant a protection order when sentencing someone for a family violence offence. ${ }^{28}$ No application has to be made; the court acts without prompting. A family violence offence is an offence against any enactment that involves family violence, so it goes beyond breaches of protection orders. There must however be a "family relationship", as defined in ss 12-14 of the FVA. This includes spouses and partners, but also extends to family/whānau, those who share a household (for example, flatmates) and those in close personal relationships (for example, those who are "dating" or were once best friends).

23 At [37].

24 See a similar reference in the principles of the Act: FVA, s 4(c). More generally, see Evan Stark Coercive Control: How Men Entrap Women in Personal Life (Oxford University Press, New York, 2007).

25 FVA, s 4(f).

26 Section 11(1)(f).

27 Judith A Davey and Jayne McKendry Financial abuse of older people in New Zealand (Institute of Policy Studies, Working Paper 11/10, November 2011).

28 When the Bill was split, it became the Sentencing Amendment Act (No 2) 2009, s 4; incorporating ss 123A$123 \mathrm{G}$ into the Sentencing Act 2002. 
The criminal court can thus grant a civil order but subject to two conditions: ${ }^{29}$

(a) the court must be satisfied that "the order is necessary for the protection of the victim of the offence"; and

(b) the victim of the offence must not object to the making of the order.

The first condition is redolent of s 79 of the FVA, as necessity is a requirement for getting a protection order. Necessity is discussed later in this article (Part V). Suffice it to say that case law has developed a distinct approach to this issue.

The second condition has given rise to some question marks. Does the sentencing court have to take an initiative to see what the victim's opinion is? Arguably, it should out of respect for the victim. As Andrews J said, "one cannot object to something of which one is not aware". ${ }^{30}$ On the other hand, the policy framework for family violence (which, for instance, is to recognise family violence in all its forms as unacceptable, to stop and prevent family violence, and to keep victims safe ${ }^{31}$ justifies an approach whereby the victim's consent is not needed, and only the absence of objection is required..$^{32}$ So, the sentencing court can act somewhat unilaterally unless the victim has independently taken positive steps to object. This is nevertheless in contrast to the FVA law on applications for protection orders made by a representative. Under ss 69(4) and 74(2), reasonable steps have to be taken to ascertain the victim's views on the application and only then will the lack of objection or an objection "not freely made" permit the progress of the application. The conclusion is that the civil law and the sentencing laws are not marching in step with each other.

This raises a broader query about the part played by the criminal courts in awarding protection orders. The query cannot be downplayed because the number of respondents and associated respondents is significant: 1,108 were dealt with on sentencing in $2020 .{ }^{33}$ To what extent can judges steeped in the criminal law, rather than family law, be trusted to get the granting of protection orders right? Family Court judges are appointed because of their particular aptitude and they receive ongoing training. They are familiar with the law on protection orders, whereas the criminal law judge may be less so. Should we be worried that sentencing judges will be either too liberal in granting orders, or too stingy?

29 FVA, s 6(2)(a)-(b).

30 Broderick v Police [2014] NZHC 133, [2014] NZFLR 406 at [25].

31 FVA, s 3(1), which describes the purpose of the Act.

32 Te Kani v Police [2014] NZHC 82, [2014] NZFLR 400 at [23] and [24] per Mander J.

33 See Table 4: Number and percentage of respondents/associated respondents of Protection Order applications, by court jurisdiction, gender, ethnicity and age, 2011-2020, available at "Data tables", above n 18. 
What may be seen as the leading case is Solicitor-General v Karekare. ${ }^{34}$ Following conviction for offences against the offender's ex-partner, no protection order was granted. The Crown successfully appealed. According to Jagose $\mathbf{J}$, the trial Judge had "placed the onus on the victim to manage her [own] situation and safety" by drawing a negative inference from her failure to seek a protection order herself. ${ }^{35}$ A protection order should have been made. Importantly, Jagose J said this: "I acknowledge that finding comes close to being one that a protection order should follow in all but exceptional circumstances on conviction for domestic violence". ${ }^{36}$ This may sound extreme to the average lawyer: the Judge is in effect saying that an order is presumed unless the offender can point to "exceptional" reasons to the contrary. This is not the approach a civil judge would take to an application under the FVA (though in Part V we shall discuss Surrey $v$ Surrey, where a heavy onus is said to shift to the defendant). ${ }^{37}$ The judge must be sure that the evidence reveals family violence and a need for an order. On the other hand, the sentencing judge is dealing with a very different situation: the offender has been found guilty of a family violence offence, so that the existence of family violence is not in issue. Jagose $\mathrm{J}$ continued: ${ }^{38}$

I recognise domestic violence is characterised by its ongoing pattern and that is what we are asked to look

at, whether there is past violence and a reasonable foundation for a fear of future violence.

On the face of it, Karekare fetters the court's discretion on whether or not to award a protection order in a way that is not flagged in the legislation. Yet it can be seen in a different light when evaluated against the purpose and principles of the FVA. ${ }^{39}$ The footnote to this is that, in the context of family violence, the civil and criminal laws interact.

\section{Police Safety Orders}

The same legislation that allowed sentencing judges to grant protection orders, the Domestic Violence (Enhancing Safety) Bill 2008, also introduced Police safety orders (PSOs). ${ }^{40}$ The relevant law is now found in pt 3 of the FVA, located ahead of the part that deals with protection orders. Like

34 Solicitor-General v Karekare [2019] NZHC 849, [2018] NZFLR 1038 (note the seemingly prescient reporting of a 2019 judgment in 2018 is a playful quirk of the reporting system).

35 At [16]-[17].

36 At [26].

37 Surrey v Surrey [2008] NZCA 565, [2010] 2 NZLR 581; discussed in SN v MN [2017] NZCA 289, [2017] 3 NZLR 448

38 Solicitor-General v Karekare, above n 34, at [26].

39 FVA, ss 3 and 4.

40 When the Bill was split, this became the Domestic Violence Amendment Act 2009, s 9. See generally Bill Atkin and Sean Brennan "Police safety orders in New Zealand: Getting the balance right?" (2016) 8 NZFLJ 176. 
the sentencing changes, PSOs have had considerable impact judging by the numbers granted. In 2020 , 24,264 PSOs were issued and 1,998 were breached (compare 6,218 protection order applications in 2020). ${ }^{41}$

PSOs are awkwardly named as they are not about police safety but the safety of family violence victims. The role of the police is, however, critical because these civil orders are granted not by a judge but by a qualified police constable and, in some instances, by an unqualified one. A qualified constable is one with the rank of sergeant or higher, but a qualified constable can "specifically" authorise an unqualified constable to issue a PSO. ${ }^{42}$ It follows that the power to issue PSOs can be used by any police officer, even a newly recruited one. They can be issued only in the context of family relationships and only where the constable has reasonable grounds for believing that an order is necessary for the safety of one of the parties. ${ }^{43}$ The ostensible victim does not have to consent and, unlike protection orders on sentencing, an objection will not act as a veto. ${ }^{44}$ Nor is there any requirement to seek the parties' views, but the welfare of children must be considered along with any potential hardship. ${ }^{45}$ Unlike the conditions for a protection order, it is not necessary to show past or present family violence; this is simply a factor that the constable must have regard to. ${ }^{46}$ The consequences of a PSO are extensive as the "bound person" must quit the home and parenting orders are automatically suspended. ${ }^{47}$ The main mitigating factor is that they last only for a maximum of 10 days, a figure increased from five days when the FVA was passed. ${ }^{48}$

Given the large number of orders granted, sometimes the police can get the parties the wrong way round or grant an order when there is no legal basis for doing so. ${ }^{49}$ Despite this, the FVA provides no mechanism for reviewing an order. There is no appeal or review process. The order cannot be undone or modified, but the effects may linger, for example by being brought into play in other proceedings,

41 "Police Safety Orders (PSOs) issued and breached for the year 2020 by month" (obtained under Official Information Act 1982 request to the New Zealand Police). See also Table 3: Number and percentage of Protection Order applications, by application type, 2011-2020, available at "Data tables", above n 18.

42 FVA, s 28(3).

43 Section 28(1)-(2).

44 Section 30.

45 Section 29(1)(c)-(d).

46 Section 29(1)(a)

47 Sections 36 and 41.

48 Section 35. Compare Domestic Violence Act 1995, s 124K (repealed).

49 Elaine Mossman, Venezia Kingi and Nan Wehipeihana An Outcome Evaluation of Police Safety Orders (New Zealand Police, 11 June 2014) at [6.4]. 
such as parenting orders under the COCA. ${ }^{50}$ Unlike protection orders, breach of a PSO is not an offence, but there can be significant consequences. For example, the bound person can be the subject of an arrest warrant, taken into custody, face a "complaint" to the District Court, and be issued with a further PSO or a temporary protection order. ${ }^{51}$ So, although not described as an offence, contravention of a PSO has many of the hallmarks of an offence. In Mark $v$ Police, Collins J, perhaps not surprisingly, held that the burden of proof was beyond reasonable doubt, ie the criminal one. ${ }^{52}$ The FVA changed this: s 49 specifies that the standard of proof is the softer civil one of the balance of probabilities. Curiously, however, s 48 states that the District Court's jurisdiction is criminal. It follows that the criminal court decides any issue relating to contravention, but using the civil standard. If ever the boundaries between civil and criminal law have been blurred, surely this is a classic example.

Apart from the specific points about the operation of PSOs, the much wider constitutional question arises of using the police to perform a central function of the judiciary and to grant civil orders. We accept that the police can do things like issue speeding tickets, but this is part of implementing the criminal law, which is a prime police function. PSOs are very different and have serious consequences, as noted. At one level, this is an affront to our constitutional sensibilities and understanding of the rule of law. On the other hand, family violence is a major social problem that needs to be tackled by a wide range of tools. At crucial times, these tools need to be ones that can be used in emergency situations. ${ }^{53}$ A call-out to a domestic incident will be addressed to the police, not a judge. The police can of course make an arrest but only if an arrest is warranted. This will not always be clear-cut and a device such as a PSO may well be the answer. Since the FVA, an arrest and a PSO can be combined, whereas it was either/or under the original version of the PSO law. Quick decisionmaking and flexibility are of the nature of the situation. In short, the practical reality is that the police are the only agents in a position to act. Given the priority to be given to victims, including children, one can forgive the constitutional indiscretions inherent in PSOs. However, if we take an even broader picture, our misgivings weaken if we accept that the civil/criminal divide is increasingly less applicable in the context of family violence.

50 For example, see Farrelson v Coach [2015] NZFC 3627 at [6]-[11], [45]-[49] and [89]; Kupchick v Crawford [2015] NZFC 2466 at [83]-[89]; Liyanage v Ranatunga [2015] NZFC 4397 at [14]; and Meltzer v Douglas [2014] NZFC 1549 at [64].

51 FVA, ss 43, 45, 46 and 51.

52 Mark v Police [2013] NZHC 1041, [2013] NZFLR 710 at [17]-[21] and [23].

53 For a discussion of the rights implications of without notice protection orders made usually in emergency situations, see Alison Towns and Hazel Scott "Accountability, Natural Justice and Safety: The Protection Order Pilot Study (POPS) of the Domestic Violence Act 1995" (2006) 5 NZFLJ 157. 


\section{Information Sharing}

One of the areas of concern in regard to child and family violence is the lack of co-ordination and interaction between various agencies. At times, the left hand does not know what the right hand has been doing, and the pieces of the jigsaw puzzle have not been put together. A classic example of this comes from the child abuse context and is sadly illustrated by the Children Commissioner's report into the death of James Whakaruru. ${ }^{54}$ To remedy this kind of problem, we have new information sharing regimes in each of the FVA and the OTA. ${ }^{55}$ The latter is more rigorous than the former. There are also rules about information sharing between the civil and criminal courts. At first glance, these moves make sense. An agency making decisions about personal safety should surely have the full facts. On the other hand, our society is also very concerned about breaches of privacy. We have the Privacy Act 2020, privacy codes, and a Privacy Commissioner. The select committee report in the lead up to the FVA noted concerns: ${ }^{56}$

We received just over 30 submissions on new Part 6B [now pt 2 of the FVA] of the bill, which relates to information requests, use, and disclosure, and service delivery codes of practice. Submitters drew our attention to the relationship of trust that service providers have with victims, and how these provisions may affect that relationship. Privacy concerns were also raised, specifically about whether information sharing between agencies would be a deterrent to individuals seeking help, and whether consent should be required before information is shared.

The Committee considered that the legislation contained enough safeguards in balancing safety and privacy.

Part 2 of the FVA establishes a regime for sharing information between government agencies (including district health boards, school boards and licensed early childhood services), nongovernment organisations operating in the government sector and handling family violence matters, and individual social services practitioners (in the health, education and social work areas). The regime does not cover courts (see below) or legal practitioners, who may have other obligations and ethical rules, such as legal professional privilege. Nor does the regime cover government agencies falling outside the definition in the Act, non-government agencies that do not receive government funding, and members of the public.

54 Commissioner for Children Final Report on the Investigation into the Death of Riri-o-te-Rangi (James) Whakaruru, born 13 June 1994, died 04 April 1999 (Office of the Commissioner for Children, 2000). For further discussion of many reports, see Taylor and Ballantyne, above $\mathrm{n} 1$.

55 OTA, s 65A and following, which are more extensive and have a greater level of obligation than the information sharing provisions in pt 2 of the FVA. On information sharing under the OTA and also on the role of the High Court's inherent jurisdiction, see Attorney-General v J [2019] NZCA 499, [2020] 2 NZLR 176.

56 Family and Whānau Violence Legislation Bill 2017 (247-2) (select committee report) at 16. 
Personal information can be sought by appropriate agencies and practitioners, but agencies and practitioners can also act on their own initiative. Part 2 focuses on the following purposes found in $\mathrm{s}$ 20(1):

(a) to make, or contribute to, a family violence risk or need assessment:

(b) to make, or contribute to the making or carrying out of, a decision or plan that is related to, or that arises from or responds to, family violence:

(c) to help ensure that a victim is protected from family violence.

A request by an agency or practitioner under s 20 for personal information about a victim or perpetrator must relate to at least one of these purposes. The holder of personal information may disclose it under subs (4) if they believe on reasonable grounds that the requester will or may be helped in fulfilling the purposes listed above, and that the disclosure itself is "for use for all or any" of those purposes. Using similar language, s 24 imposes a duty to consider whether or not to disclose. Under ss 20 and 24, a duty to consider disclosure arises even if no request has been made, thus enabling a holder to at proactively in accordance with the provisions in the Act. Under s 22, a duty is imposed on all parties to comply with any code of practice issued under s 254(1) and (2)(c). Under s 21, the holder of information "must have regard" to the precedence that the principle of victim protection should usually take over both any duty to keep information confidential and over limits on the disclosure of information in the privacy legislation.

The disclosure regime does not override ss 236 and 237 of the District Court Act 2016, nor ss 173 and 174 of the Senior Courts Act 2016 on accessing court information. ${ }^{57}$ Rules of privilege in the Evidence Act 2006 are also not affected, but privilege that arises in, for example, FGCs and mediations as part of family dispute resolution is not mentioned. The privilege in these contexts is, however, limited to the presentation of evidence in court or in relation to someone "acting judicially", and arguably, the parties to the information sharing regime in pt 2 of the FVA are not "acting judicially". 58

Evidence of a person's criminal record may affect proceedings under the FVA. Rule 316A of the Family Court Rules 2002 states that:

If a respondent to an application under the [Family Violence] Act for a protection order is or has been involved in a criminal proceeding, the Criminal Procedure (Transfer of Information) Regulations 2013 may apply.

57 FVA, s 23. See also the Senior Courts (Access to Court Documents) Rules 2017; and the District Court (Access to Court Documents) Rules 2017.

58 See Family Dispute Resolution Act 2013, s 14(2); and McKay v Commissioner of Inland Revenue [2018] NZCA 138, [2018] NZFLR 477 at [11]-[13] and [40]-[42]. 
Those Regulations permit the registrar of a court handling a family violence proceeding to get details of a criminal record from the court file, database or permanent court record, and obliges them to make those details available to the court dealing with the protection order application or follow-up proceeding. ${ }^{59}$ The "criminal record" refers to charges laid against the respondent that have resulted in a conviction, convictions entered against the respondent, sentences imposed on the respondent and orders imposed on the respondent as a result of a conviction. ${ }^{60}$ The provisions on the sharing of information between the civil and criminal courts were added in $2015 .^{61}$

The various information rules go beyond the civil law/criminal law distinction. Indeed, they can be seen as part of a wider transformation taking place to the public service, captured in the Public Service Act 2020. One of the purposes of the Act as set out in s 3(c) is "to establish organisational forms and ways of working, including across public service agencies, to achieve better outcomes for the public". In furtherance of this purpose, the Act provides for interdepartmental boards, joint operational agreements and interdepartmental ventures in $\mathrm{pt}$ 2. One of the stand-out examples of the latter is the Joint Venture for Family Violence and Sexual Violence and cross-agency efforts to reduce family and sexual violence. ${ }^{62}$ This involves the chief executives who are on the Social Wellbeing Board: those of the Department of Prime Minister and Cabinet, Oranga Tamariki, Health, Te Puni Kōkiri, Social Development, Education and Justice, with the addition of Police, ACC and Corrections. ${ }^{63}$ It follows, therefore, that one of the main themes of this article (that the civil/criminal distinction has far less of a place in the context of family violence than it does in other areas of the law) is part of a much bigger picture which has constitutional and administrative implications that cannot be more than noted here.

\section{CRIMINAL LAW DEVELOPMENTS}

Recently, the criminal law has drawn on the FVA as it has expanded to address family violence. Often in the past, the principal offence used has been male assaults female, found in s 194 of the Crimes Act. This offence is, however, general and not specific to family violence. Since 3 December 2018, we have a new offence of "[a]ssault on person in family relationship" in s 194A of the Crimes Act:

59 Criminal Procedure (Transfer of Information) Regulations 2013, reg 7A(1) and (2).

60 Regulation 7A(3).

61 Regulation 7A was inserted on 1 September 2015 by reg 7 of the Criminal Procedure (Transfer of Information) Amendment Regulations 2015.

62 See "The Joint Venture for Family Violence and Sexual Violence (Joint Venture) and cross-agency efforts to reduce family and sexual violence" Ministry of Social Development <www.msd.govt.nz>.

63 See $Q \& A$ : Joint venture model to lead prevention and reduction in family violence and sexual violence (Ministry of Justice, September 2018). This document is available at "Family violence \& sexual violence work programme" (13 August 2020) Ministry of Justice <www.justice.govt.nz>. 
(1) Everyone is liable to imprisonment for a term not exceeding 2 years who-

(a) assaults another person; and

(b) is, or has been, in a family relationship with that other person.

The term "family relationship" has the same meaning as in s 12 of the FVA. ${ }^{64}$ This new offence is therefore limited to situations that arise in the context of family violence, and it is not gendered. The maximum sentence of two years imprisonment is the same as for a s 194 offence, but one year less than the offence of breach of a protection order. ${ }^{65}$ Section 194A makes no reference to family violence as such, but an assault will be an example of family violence. More importantly, inflicting family violence is not as such an offence. ${ }^{66}$ Many instances of family violence, especially psychological abuse and ongoing coercive behaviour, are not covered. In the United Kingdom, for example, the latter is found in s 76 of the Serious Crime Act 2015 (UK), although it must have a serious effect on the victim that the abuser was, or ought to have been, aware of. New Zealand has not moved down this route.

What is the advantage of the new offence? Apart from the symbolism of raising the profile of family relationship offending in a general sense, it also connects with another change - the introduction of the family violence offence flag. ${ }^{67}$ This is provided for in s $16 \mathrm{~A}$ of the Criminal Procedure Act 2011. Although the section has some complexities, in short it means that the charging documents and permanent record will contain a notification that an offence is a family violence one. This may have some impact on bail, sentencing, and future civil and criminal proceedings. A "family violence offence" unsurprisingly includes a breach of a protection or property order, but significantly any offence that involves "family violence" as defined in the FVA. ${ }^{68}$ Thus, the interaction between the criminal law and the civil law comes back into focus in a much broader way. It follows that determining whether an offence is a family violence one requires an understanding of the civil law and a keen eye in assessing the underlying nature of offences that, on the surface, may not have a family connection. The new offence in s 194A of the Crimes Act will be obvious. Other offences such as ones against property may be more subtle but nevertheless should attract the flag.

There are two other new offences that could impliedly be seen as family violence offences in the general run of events. These are "[s]trangulation or suffocation" in s 189A and coerced marriage or

64 Crimes Act 1961, s 194A(2).

65 FVA, s 112(3).

66 Among other discussions of this question, see Heather Douglas "Do We Need a Specific Domestic Violence Offence?" (2015) 39 MULR 434.

67 For an excellent discussion, see Mereana White "Using The 'Family Violence Flag' To Better Identify Harm Within Families" (LLM Thesis, Victoria University of Wellington, 2020).

68 Criminal Procedure Act 2011, s 16A(5). 
civil union in s 207A of the Crimes Act. The latter is explicitly about family relationships, and, as coercion is used, the situation is almost certainly a case of psychological abuse. Indeed, the examples of coercion given in s 207A(1) of "intimidation, threats, or violence" are examples of abuse under the FVA. "Strangulation or suffocation" in s 189A is a very serious offence with a maximum sentence of 7 years imprisonment. While it is not limited to the family situation, it is a form of abuse that relates to control and coercion within such situations. ${ }^{69}$ It is likely to often attract the family violence flag.

Another change to criminal procedure that draws on the civil law is s 9(1)(ca) of the Sentencing Act 2002. An aggravating factor in sentencing is where the offence was a family violence offence against a person who had a protection order against the offender. "[F]amily violence offence" is defined in the same way as it is for the flag. ${ }^{70}$ The same definition applies under s 3 of the Bail Act 2000 (as inserted on 3 December 2018). Under s 30AAA of the Bail Act, where bail is granted in relation to a family violence offence, conditions can be imposed to protect the victim, or anyone residing with or in a family relationship with the victim.

\section{DIFFERENCES BETWEEN THE CIVIL AND CRIMINAL LAW NEVERTHELESS REMAIN CRUCIAL}

A degree of convergence between the civil and criminal law of family violence has been outlined. Such convergence can, of course, go only so far. Rules on procedure and evidence vary with understandably greater safeguards in criminal hearings. In fact, in civil cases the "any evidence" rule in s 12A(4) of the Family Court Act 1980 allows "the court hearing the proceeding [to] receive any evidence, whether or not admissible under the Evidence Act 2006, that the court considers may assist it to determine the proceeding". The rule is controversial, but this is not the place to explore the issue. ${ }^{71}$

Perhaps the greatest divergence is in relation to the onus of proof. The standard of proof varies: beyond reasonable doubt for the criminal law, and the balance of probabilities for the civil law. This is so entrenched in the law that it barely needs to be mentioned but it does mean that "family violence" may be proven for civil law purposes, but not for the criminal law. Because of the lower standard of proof required, a civil court may logically accept a finding of the criminal court, but not vice versa.

These points have not, in practice, caused real problems. Yet, we need to delve more deeply into the way in which the civil law has moved. The conventional legal rule is that the onus of proof rests on the party who is making a claim, seeking an order or pursuing a charge. When it comes to protection orders, the Court of Appeal has shifted the goalposts or even removed them. In the leading case of

69 See references in Taylor and Ballantyne, above $\mathrm{n}$ 1, at [3.4.4].

70 Sentencing Act, s 123A.

71 See Anna High and Caroline Hickman "The 'Any Evidence' Rule in New Zealand Family Law" (2020) 29 NZULR 49 
Surrey $v$ Surrey,${ }^{72}$ the husband had among other things raped his wife and sent his daughter texts that were entirely inappropriate (to put it mildly) ${ }^{73}$ The High Court had reversed the Family Court's award of a protection order, partly on the grounds that the behaviour could be dismissed as being "situational". ${ }^{74}$ Leaving aside any surprise at this assessment of the facts, we can well understand how the Court of Appeal saw things in quite the opposite way. The Family Court ruling was upheld. ${ }^{75}$ However, the Court of Appeal went much further than reviewing the facts. The requirements for a protection order under s 79 of the FVA are that family violence has been or is still being inflicted, and that the order is "necessary" for the applicant's protection or that of a child of the applicant's family. Under s 83, the court must, inter alia, consider the applicant's perception of the behaviour in respect of which the application is made. How are these provisions to be interpreted?

The Court of Appeal held that the High Court had wrongly imposed a burden on the applicant to prove that future violence was likely. ${ }^{76}$ This move away from a burden on the applicant is arguably justified by the serious nature of family violence and the social policy in preventing it. ${ }^{77}$ Furthermore, there are other family law contexts, very different from family violence, where it is stated that the idea of a burden of proof is inappropriate, such as relationship property and maintenance. ${ }^{78}$ However, the Court then went further. It held that, where the applicant proves "past violence and a reasonable subjective fear of future violence", an evidential burden shifts to the respondent. ${ }^{79}$ While described as an evidential burden, which contrasts with the full legal burden, any "countervailing" factors will nevertheless have to be "very strong indications that the order is not necessary". ${ }^{80}$ This looks like rather more than an evidential burden, and furthermore, the shift in onus - or presumption in favour of the applicant, to put it another way - is a gloss on the language of the statute. The lightening of the load on the applicant also stands in marked contrast to the load instead placed on the respondent. There are ironies here that are nevertheless justified by the social policy already mentioned.

What is obvious is that the civil law, in its treatment of onus and proof, has launched down a very different path from the criminal law.

72 Surrey v Surrey, above n 37.

73 At [9]-[10].

74 At [26]-[28] and [35]-[36].

75 At [85].

76 At [36].

77 FVA, s 3(1)(b).

$78 X v X$ [Economic disparity] [2009] NZCA 339, [2010] 1 NZLR 601 at [95]; and McQueen v Penn [2016] NZCA 571, [2017] NZFLR 31 at [20].

79 Surrey v Surrey, above n 37, at [77].

80 At [37] and [43]. 


\section{CONCLUDING REMARKS}

To the conventional legal mind, the civil law and the criminal law are very different creatures. However, in the context of family violence law, this is far less accurate. In this article, examples of the civil/criminal law interplay have been given at various levels, from court processes to high level policy. It is hard to predict how the trend will continue. One possibility is the creation of one specialist court to deal with family violence, already being trialled in places. Zoë Lawton has advanced this idea with some passion, but its time has not yet come. ${ }^{81}$ The other strand is reflected in the cutting-edge report of the Independent Panel that the Minister of Justice established to look at the family justice system. ${ }^{82}$ While not tasked to address family violence in any significant way, the motifs in the report apply more widely. In particular, the FVA may need to be assessed in relation to the rights of children and those with disabilities, and the extent to which it responds to diversity. More importantly, the Panel's report called for much greater recognition of te ao Māori. ${ }^{83}$ As noted at the start of this article, the OTA has taken strides in this regard, along with the Rangatahi Courts, Ngā Kōti Rangatahi, for youth justice. ${ }^{84}$ However, this is hardly true of the FVA and accompanying criminal law legislation. Maybe this is the next major phase of development, conceivably integrated with the Lawton proposal for one court, one judge handling both civil and criminal cases.

81 Zoë Lawton One Court, One Judge: An Integrated Court System for New Zealand Families Affected by Violence (New Zealand Law Foundation, 2017).

82 Te Korowai Ture ā-Whānau: The final report of the Independent Panel examining the 2014 family justice reforms (Ministry of Justice, May 2019).

83 At [40]-[60].

84 "Rangatahi Courts \& Pasifika Courts" Youth Court of New Zealand <https://youthcourt.govt.nz>. 
(2021) 52 VUWLR 